\title{
FRAME MARKERS AND COHERENCE IN L2 ARGUMENTATIVE ESSAYS ${ }^{1}$
}

\author{
Višnja Pavičić Takač and Sanja Vakanjac Ivezić
}

\begin{abstract}
Academic literacy includes the learners' ability to use their language knowledge to form articulate texts. In communicative competence models this ability is subsumed under the notion of discourse competence which includes the concepts of cohesion and coherence. Starting from the premise that constructing a coherent text entails efficient use of metadiscourse (i.e. means of explicit text organisation) this study focuses on elements referring to discourse acts, text sequences or stages called frame markers, i.e. items providing framing information about elements of the discourse and functioning to sequence, label, predict and shift arguments, making the discourse clear to readers or listeners (Hyland 2005). It analyses patterns of L2 learners' use of frame markers, compares them to English native speakers', and explores the relationship between frame markers and coherence. The corpus includes 80 argumentative essays written by early undergraduate Croatian L2 learners of English at B2 level. The results indicate that foreign language learners' argumentative essays are characterized by an overuse of a limited set of frame markers. Finally, implications are drawn for teaching and further research.
\end{abstract}

\section{Keywords}

metadiscourse, frame markers, coherence, discourse competence, L2 writing

\section{Introduction}

Discourse competence, conceptualized as the ability to make connections between form and meaning in order to create meaningful spoken or written texts, is an important aspect of second language (L2) learners' communicative competence. In most communicative competence models the component of discourse competence includes the concepts of cohesion and coherence (cf. Canale 1983, Bachman 1990, Celce-Murcia 1995, Bachman \& Palmer 1996, CEFR 2001, Celce-Murcia 2007, Bagarić Medve \& Pavičić Takač 2013a). Although the above mentioned models define cohesion similarly, a review of relevant literature (e.g. Halliday \& Hasan 1976, van Dijk 1977, Widdowson 1978, Carell 1982, Brown \& Yule 1983, Canale 1983, Savignon 1983, Dastjerdi \& Talebinezhad 2006) suggests that there is no general agreement regarding the concept of coherence. As for the relationship between the two concepts, most applied linguists agree that although cohesion does not necessarily spawn text coherence, it can help to improve it. This is why exploring the ways in which 
cohesion contributes to establishing coherence presents an intriguing area of applied linguistic research. While there is a substantial body of research on cohesion, whose findings typically point to over- or underuse, misuse or lack of variation of textual/interactive metadiscourse markers in L2 learner writing (cf. Section 4), appropriate usage of metadiscourse as an indicator of coherence is generally under-researched. The present study is a step towards meeting the growing need to explore more extensively the relationship between metadiscourse and coherence in argumentative essays written by L2 learners of English.

The organisation of the paper is as follows: Section 2 defines metadiscourse and outlines the categorisation of metadiscourse, Section 3 provides a detailed description of the category of frame markers, and Section 4 summarizes previous empirical research pertinent to this study. Subsequent sections contain a full description of our study and the discussion of the results. The paper ends with a discussion of pedagogical implications and suggestions for future research.

\section{On metadiscourse}

Although a wide range of different labels has been used to refer to linguistic means used by writers to structure and organize the text (e.g. discourse markers, cohesive devices, pragmatic markers, discourse or pragmatic particles, pragmatic expressions or connectives; cf. Jucker \& Ziv 1998: 1, Hůlková 2005: 53-54, Vogel 2008: 120), the term 'metadiscourse' is increasingly used by linguists in current discourse analysis as an umbrella term to include a variety of cohesive and interpersonal features which help to relate a text to its context (Hyland 2005: 16). Vande Kopple (1985) and Crismore et al. (1993) define metadiscourse as: "linguistic material in texts, written or spoken, which does not add anything to the propositional content but that is intended to help the listener or reader organize, interpret and evaluate the information given" (Crismore et al. 1993: 40). Non-propositionality as a defining characteristic of metadiscourse is also prominent in Hyland's view of metadiscourse. He argues that metadiscourse embodies "the idea that communication is more than just the exchange of information, goods or services, but involves the personality, attitudes and assumptions of those who are communicating" (Hyland 2005: 3). This approach refers to the ways writers or speakers project themselves in their texts to interact with their receivers. They do not simply produce a text to convey information but try to ensure that the information is understandable and acceptable. In short, according to Hyland (2005), metadiscourse is considered an essential means of facilitating both spoken and written communication.

The introduction of the notion of metadiscourse has contributed to a range of recent work in text analysis. Most studies have focused on metadiscourse as a 
feature of written discourse, i.e. on metadiscourse as the linguistic device writers employ to shape their arguments to meet the needs and expectations of their target readers (Hyland 2004: 134). As a result, metadiscourse has been shown to be a feature of good writing, both native and non-native, which helps writers to express their ideas and engage with their readers (Cheng \& Steffensen 1996, Intraprawat \& Steffensen 1995, Hyland 2005). Moreover, metadiscourse plays a central role in persuasive and argumentative discourse by improving readability and persuasiveness of the propositional content (cf. Crismore \& Farnsworth 1990, Hyland 1998, 2004, 2005).

Various taxonomies of metadiscourse elements have been proposed since the initial interest arose some decades ago (cf. Vande Kopple 1985, Crismore 1989, Crismore et al. 1993, Hyland 2005, Ädel 2006). Most of these classifications are based on Halliday's (1994) three-part conception of metafunctions, which distinguishes between the ideational elements of a text, that is the ways we encode our experiences of the world, and its textual and interpersonal functions (Hyland 2004: 137). The most substantial revision of previous taxonomies has been proposed by Hyland (2005). His model has become one of the most widely used ones in the field of L2 academic writing research. In his attempt to address the limitations and drawbacks of previous models, he collapsed, separated and reorganized the existing metadiscourse categories. For example, Hyland deemed Crismore et al.'s division of textual metadiscourse into textual and interpretive markers unnecessary as "organizational features obviously contribute to the coherence of the text and thereby assist the reader in interpreting it" (Hyland 2005: 33). He further pointed to the confusion this categorisation may lead to by drawing attention to the following examples: reminders, which refer to material earlier in the text, are seen as textual, whereas announcements, which refer to material appearing later, are seen as interpretive markers. Hyland's model emphasises the following three key principles of metadiscourse: it is distinct from propositional aspects of discourse; it refers to aspects of the text that embody writer-reader interactions; and it refers only to relations which are internal to the discourse (Hyland 2005: 37-38). It comprises two main categories, the interactive and interactional, which are further divided into several subcategories. The interactive and interactional categories are the defining characteristics of any communication and are expressed through a range of rhetorical features which perform more specific functions. Given that the current study relates to the former, it will be briefly presented.

The interactive dimension of metadiscourse concerns the writer's awareness of his receiver. It addresses ways of organising discourse with the readers' needs in mind. The interactive features are not simply text-organizing but are 
"a consequence of the writer's assessment of the reader's assumed comprehension capacities, understandings of related texts, and need for interpretive guidance, as well as the relationship between the writer and reader" (Hyland 2005: 50). There are five broad interactive subcategories: transition markers, frame markers, endophoric markers, evidentials and code glosses. Transition markers signal additive, causative and contrastive relations, expressing relationships between stretches of discourse; frame markers frame information about elements of the discourse and function to sequence, label, predict and shift arguments; endophoric markers facilitate comprehension and support arguments by referring to earlier material or material appearing later; evidentials involve attribution to a reliable source and provide support for arguments; and code glosses provide additional information by rephrasing, explaining or elaborating in order to recover the writer's intended meaning (ibid.: 50-52). Since the present study focuses on frame markers as one of the subcategories of the interactive dimension, they warrant a more detailed description.

\section{Interactive metadiscourse and frame markers}

Frame markers figure in many taxonomies of metadiscourse, albeit differently labelled and classified according to different criteria. Thus, Vande Kopple's (1985) early model contains two subcategories of interactive metadiscourse which perform the same function as the four subcategories of Hyland's (2005) frame markers: text connectives and illocution markers. Text connectives help to show how parts of the text relate to each other and include sequencers (first, next), reminders about material presented earlier in texts (in chapter one), announcements of material appearing later in texts (in the next section) and topicalizers reintroducing information or explicitly connecting new information to information already presented (as for, in regard to). Illocution markers are used to make explicit for readers what specific action we are performing at a particular point, for example, to hypothesize, sum up or make claims (to conclude, to sum up) (ibid.: 83-84). Following this first systematic taxonomy, Crismore et al. (1993) proposed a revised model whose categorisation is based on particular pragmatic functions. The textual metadiscourse was further divided into the categories of textual and interpretive metadiscourse. These two new categories are supposed to account for the textual role of metadiscourse, with textual markers referring to features which help to organize the discourse and interpretive markers which function to "help readers interpret and better understand the writer's meaning and writing strategies" (ibid.: 47). Subcategories that functionally parallel Hyland's (2005) frame markers are features of textual metadiscourse, i.e. sequencers indicating sequence (first, next), reminders referring to information mentioned 
earlier in the text (in chapter one) and topicalizers indicating a shift in topic (now we discuss), as well as features of interpretive metadiscourse, i.e. illocution markers naming the act performed (to conclude, to sum up) and announcements announcing upcoming material (in the next section).

As briefly noted above, frame markers in Hyland's model (2005) are defined as items providing framing information about elements of the discourse and functioning to sequence, label, predict and shift arguments, making the discourse clear to readers or listeners. There are four subcategories of frame markers: sequencing, labelling stages, announcing goals and shifting arguments. Frame markers can therefore be used to sequence parts of the text or to internally order an argument, often acting as more explicit additive relations (first, then, at the same time, next, etc.), they can explicitly label text stages (to summarize, in sum, etc.), announce discourse goals (I argue here, my purpose is, there are several reasons why, etc.) and indicate topic shifts (well, right, OK, now, let us return to, etc.) (Hyland 2005: 51). Functionally, Hyland's frame markers largely correspond to what Biber et al. (1999) call linking adverbs (or what Halliday and Hasan (1976) call conjunctive adjuncts) which are defined as devices serving to make explicit the relationship between units of discourse and thus contribute to textual coherence. Some of the frame markers also correspond to particular semantic categories of linking adverbials, for example, the subcategory of frame markers for sequencing express addition and enumeration (e.g. first) and frame markers for labelling stages express summation (e.g. in sum). As for their syntactic forms, frame markers in Hyland's model encompass adverbs (e.g. so), adverb phrases (e.g. first and foremost), prepositional phrases (e.g. in conclusion), noun phrases (e.g. purpose), clauses (e.g. to conclude) and sentence stems (e.g. in this part, would like to).

Interactive metadiscourse is essential in organising any text, but it is assumed to be of critical importance in argumentative writing because it creates a communicative need for writers to heavily rely on textual metadiscourse to construct a text with the reader's needs in mind (Ädel 2006, Hyland 2005, Crismore 1989, Granger \& Tyson 1996). The use of textual metadiscourse addresses ways of how writers guide the readers and shape a text to ensure understanding of their ideas in a way that the readers are likely to find coherent and convincing (Hyland 2005). It is assumed that frame markers, i.e. words and phrases which help structure the local and global organisation of the text, actually serve the purpose of cohesive devices and may play a particularly important role in establishing coherence. They contribute to the readability of texts by conveying logical linkage between ideas in the texts and thereby increasing their level of cohesion (Vogel 2008: 120). Since the present study aims at exploring the relationship between frame markers and coherence, it starts from the premise 
that constructing a coherent text entails the ability to use metadiscourse (cf. Ädel 2006, Hyland 2005), i.e. that frame markers may play a particularly important role in establishing coherence.

\section{Review of relevant studies}

A number of studies have compared the use of metadiscourse in L2 writing to that of native speakers (e.g. Milton \& Tsang 1993, Granger \& Tyson 1996, Altenberg \& Tapper 1998, Milton 2001, Bolton et al. 2002, Narita et al. 2004, Ädel 2006, Chen 2006, Vogel 2008, Shaw 2009). Those studies may have included different items (or differently labelled and classified items), but they all analysed items that perform metadiscursive functions. Regardless of the participants' L1, the context in which the study took place, the register and genre of texts and the L1 corpus referred to for comparison (e.g. published L1 academic writing or a corpus containing essays written by native speaker students), the results seem to indicate that L2 writers overuse, underuse, misuse or use a limited number of unvaried metadiscourse items. For example, Granger and Tyson (1996) investigated connector usage in argumentative essay writing by comparing the French sub-corpus of the International Corpus of Learner English (ICLE) with the Louvain Corpus of Native Essay Writing (LOCNESS, cf. Granger 1993), which is composed of argumentative essays written by university students, half speakers of American English (AmE) and half speakers of British English (BrE). Although the authors' initial hypothesis that the L2 learners overuse connectors in their essays was not supported by quantitative analysis, a more detailed qualitative analysis revealed that L2 learners overuse the connectors that add to, exemplify or emphasize propositions and underuse adversative connectors. Similarly, Altenberg and Tapper's (1998) study, which compared essays from the Swedish component of the ICLE (SWICLE) with a native English control corpus consisting of essays by British university students, showed that advanced L2 learners overuse and underuse individual connectors, but generally underuse conjuncts. The similarities and differences between the two learner groups in the two studies suggest that L2 learners' connector usage might not be considerably influenced by their mother tongue (Altenberg \& Tapper 1998). Ädel (2006) also compared the SWICLE subcorpus with the LOCNESS corpus. She revealed that all investigated metadiscourse markers were overused by L2 writers. Vogel's (2008) analysis comparing the use of intersentential cohesive devices in essays written by Czech students majoring in English and academic papers of English native speakers also confirmed the expected higher frequency of sentence linkers in the L2 writing sample. The author concluded that the abundance of 
metadiscourse markers (in this case sentence linkers) might be one of the stylistic features which distinguishes between texts written by L1 and L2 writers.

Many studies carried out in the Asian context yielded similar results. Milton and Tsang (1993) compared the Hong Kong L2 student corpus with two L1 corpora (the American Brown Corpus and its British counterpart, the LOB Corpus) and the Hong Kong University of Science and Technology Corpus consisting of extracts from Computer Science textbooks. The results showed a clear pattern of overuse of an entire range of logical connectors in students' writing samples. A qualitative analysis of two specific connectors, moreover and therefore, showed that learners either misused the connectors (i.e. the use of the logical connector was misleading) or used them redundantly (i.e. the logical connector was not necessary and did not contribute to the overall coherence of the text) (Milton \& Tsang 1993: 228). In a comprehensive study of Chinese L2 learners' interlanguage, Milton (2001) also observed a tendency to overuse particular adverbial connectors (mainly those marking sequencing or transitions), especially in sentence-initial position, regardless of the learners' proficiency level. Chen's (2006) quantitative analysis of Taiwanese advanced L2 writers' use of conjunctive adverbs and its comparison with a corpus of published journal articles written by native speakers included two different approaches to calculating usage frequency which showed different results. Results of the word-based analysis supported the author's initial hypothesis that L2 students overused conjunctive adverbs, while those of the sentence-based approach did not. The author concluded that professional writers probably needed to use more conjunctive adverbs because they wrote longer and more complex sentences. Bolton et al. (2002) compared connector usage in three sets of data - part of the Hong Kong component of the International Corpus of English (ICE-HK), the corresponding data from the British component of ICE (ICE-GB), and a subset of published academic writing taken from ICE-GB. The results showed that both L2 and L1 students use a considerably smaller number of different connectors than professional academics, but the tendency to overuse them is much more pronounced in L2 writings (Bolton et al. 2002: 180).

An interesting study by Narita et al. (2004) compared the use of a set of 25 logical connectors in essays by advanced Japanese university students with native English writings, but also with those by advanced French, Swedish and Chinese L2 learners. Although their results indicated a shared preference of the most frequent connectors across the subcorpora, Japanese L2 learners significantly overused or underused individual connectors and showed a marked preference for using logical connectors in sentence-initial position.

Many metadiscourse studies indicated that there is cross-cultural, as well as interdisciplinary and intergeneric variation in writing produced by 
both professional and student writers from different cultural and language backgrounds. Many intercultural rhetorical analyses have looked at the use of metadiscourse in research articles from different disciplines and found more or less distinct differences between authors of English and other national cultures. For example, Dahl's (2004) comparison of research articles in three languages, English, French and Norwegian, and three disciplines, economics, linguistics and medicine, showed that much more metatext was used in English and Norwegian writing within economics and linguistics, but, within medicine, little metatext was used in all three languages. She concluded that culturally-based conventions were more important in the disciplines that create their findings through argumentation, i.e. economics and linguistics. Studies comparing native and non-native research articles in English found that writing in L2 English tends to imitate the conventions of Anglophone writers (e.g. Mur-Dueñas 2011, Murillo 2012). Similarly, Povolná (2016) observed only minor differences between Slavonic (Czech and Slovak) and Anglophone writers, which she attributed to either the writers' personal style or general inclination of Slavonic writers to adhere to the principles of the Anglophone style in academic writing. Chen and Zhang (2017) compared metadiscourse features in applied linguistic articles in Chinese and English and found differences in the frequency of use and the number of linguistic expressions between the two groups of academic writers. Nonetheless, both groups showed similar patterns in the choice of metadiscourse categories, which the authors again attributed to the Chinese writers trying to make rhetorical and stylistic accommodations to English academic discourse norms. However, other comparisons of the use of metadiscourse features in English and Chinese research articles (Hu \& Cao 2011, Mu et al. 2015) revealed significant differences between the languages, which was attributed to different culturally preferred rhetorical strategies between the English and Chinese. Similar underlying cultural differences were found by Mauranen (1993) between Finish and English economics research articles, where Anglophone writers used more metatext than the Finnish writers.

In the context of student writing, the differences between native and non-native writers in the use of metadiscourse is more evident. For example, Mirshamsi and Allami (2013) and Alipour et al. (2015) revealed significant differences in the use of both interactive and interactional metadiscourse in university students' writing in English and Persian. The authors attributed this to culturally divergent conventions as well as to the Persian L2 learners' insufficient awareness of the role of metadiscourse resulting from lack of explicit instruction on metadiscourse features. Interestingly, Kobayashi (2016) showed that not only are there various aspects of L2 writing, including the use of metadiscourse markers, influenced by 
L1 conventions, but that it is possible to distinguish between different L1 groups of Asian non-native writers on the basis of their use of typical metadiscursive devices. On the other hand, Crismore et al. (1993) investigated and found both similarities and differences in metadiscourse use in argumentative essays of US and Finnish students, thus providing partial evidence for the universality of metadiscourse. Because research in intercultural rhetoric has often produced the above-mentioned conflicting findings concerning metadiscourse features, the possibility that cultural differences affect metadiscourse use must be considered in further research.

Surely one of the most important questions in the field of L2 writing instruction is whether the use of metadiscourse contributes to the quality of writing. It has been addressed in several studies, but with inconsistent results. While an early study by Wolfe-Quintero et al. (1998) found no correlation between essay quality and the use of linking words, several studies provided evidence suggesting that the use of metadiscourse items can discriminate between different levels of L2 writing proficiency. Thus, Intaraprawat and Steffensen (1995) concluded that skilled writers' use of metadiscourse was characterized by both greater density and range, and Grant and Ginther (2000) found that the number of conjuncts used in essays increases proportionally to the increase of the writers' proficiency level. Jafarpur (1991) observed significant correlations between cohesive devices (which included categories following Halliday and Hasan's 1976 classification) and essay quality thus concluding that the analysis of cohesive devices can differentiate between different writing proficiency levels. On the other hand, Knoch et al. (2014) found that lower level writers used more metadiscourse than more proficient writers. A look at individual items may reveal that the difference between writers at different proficiency level lies in the types of metadiscourse items they select. For example, less proficient writers use a particular set of metadiscourse items more frequently, such as however, firstly, secondly (Kennedy \& Thorp 2002). This inconsistency may be due to different operationalisations and treatment of metadiscourse in the analysis (e.g. whether it only includes a selected set of items or larger categories) as well as the type of task (cf. Knoch et al. 2014).

To the best of our knowledge, pertinent exploration of writing produced by Croatian L2 novice writers is still scarce. The results of a study (Bagarić Medve \& Pavičić Takač 2013b) exploring, inter alia, how Croatian learners of English and German use cohesive devices indicate that their compositions are characterized by the dominant and ineffective use of simple cohesive devices. Recently, a more systematic investigation has been undertaken within the KohPiTekst project (cf. endnote 1). A preliminary study demonstrated that early undergraduate 
L2 English writers' overuse sentence-initial metadiscourse elements and are inclined to select a limited set of metadiscourse items (cf. Pavičić Takač 2018). The current study aims to complement this stream of inquiry.

\section{The present study}

The present study focuses on interactive metadiscourse. Previous relevant research in this field has documented an overuse of interactive metadiscourse in non-native writing but there is a lack of studies on the relationship between the use of metadiscourse and coherence in L2 writing. The present study aims at analysing the use of frame markers in academic argumentative essays written by L2 users of English, i.e. early undergraduate Croatian learners of English as a foreign language, and comparing the differences in use by examining the native-speakers' choices. The study also aims to explore the use of interactive metadiscourse and its role in achieving coherence in L2 academic argumentative essays. The use of interactive metadiscourse is compared against that of native speakers, but it must be pointed out that the native speaker texts do not serve as a putative model of appropriateness, but as a reference point whose sole purpose is to provide "the basis for revealing the characteristics of learner language" (Johansson 1998: 7, as quoted in Ädel 2006: 6).

The decision to focus on argumentative texts in the study was motivated by their relevance and prominence in academic writing and by the fact that this type of writing typically calls for the use of metadiscourse. The present study is also motivated by the lack of studies of metadiscourse use in early undergraduate writing, i.e. writing by students who have just transitioned into university (for exceptions cf. e.g. Aull \& Lancaster 2014 on linguistic stance markers, and Pavičić Takač 2018). Unlike more advanced student writers, who engage with academic writing and disciplinary discourses, students transitioning into university in the Croatian context receive instruction on writing within the nondiscipline-specific genre of argumentative essay only as a part of the preparation for the National Secondary School-leaving Exam in English during secondary school L2 English lessons. The idea behind the design for our corpus was to simulate a genre representing early undergraduate argumentative writing in order to explore what metadiscourse features might characterize argumentative texts produced by inexperienced incoming student writers.

In order to meet the goals of the present study, the following research questions have been formulated:

(RQ1) What is the frequency of L2 writers' use of frame markers in argumentative essays? 
(RQ2) Which subcategory of frame markers is the most frequent sub-category in L2 writers' argumentative essays?

(RQ3) How does L2 writers' use of frame markers compare with English native speakers' choices?

(RQ4) Is there a correlation between frame markers use and text coherence in L2 writers' argumentative essays?

Based on previous research findings we hypothesized that a) L2 writers use a limited set of frame markers, b) that among these the subcategory of sequencing is the most prominent, c) that they overuse a particular set of frame markers in comparison to native speakers, and d) that there is a statistically significant positive correlation between the frequency of frame markers use and coherence in L2 writers' argumentative essays.

\subsection{Methodology}

\subsubsection{Data collection procedure}

The corpus of the study consists of 80 texts written in English by early undergraduate Croatian university students at B2 proficiency level (CERF 2001). Students were given a task to write a 200- to 230-word argumentative essay in which they had to present two points of view on a controversial topic, express their opinion and give supporting arguments. In total, our corpus (hereafter EFL corpus) consisted of 19,576 tokens. ${ }^{2}$ The EFL corpus was compiled as part of the KohPiTekst research project. For the purposes of comparison, we created a corpus similar in size to ours by selecting comparable texts from the LOCNESS (cf. Granger 1993), a corpus of native English essays made up of British and American students' argumentative essays which is free and available to use for academic purposes. In total, the native speaker corpus (hereafter NS corpus) consisted of 31,062 tokens. Although the two corpora differ in the number of tokens, length of individual texts and topics, they both contain argumentative essays written by university students, which makes them sufficiently comparable.

\subsubsection{Data analysis procedure}

As has been mentioned, the focus of the study was one subcategory of the interactive dimension of Hyland's (2005) Interpersonal Model of Metadiscourse, i.e. frame markers. Hyland's model seemed to be applicable for the present study for several reasons: a) it has been developed specifically for academic text analysis which makes it applicable to the corpus of the texts analysed in this study; b) it addresses texts written by non-native writers of English, thus providing a structured basis for teaching academic writing; and c) it represents 
a synthesis of previously mentioned taxonomies of metadiscourse taking into account their strong points and limitations, and adding necessary modifications.

As regards the methodology applied in the analysis, the texts were first computer-processed using the corpus query tool SketchEngine (http://www. sketchengine.eu) and then analysed manually in order to double-check the results both qualitatively and quantitatively. During the analysis, several issues had to be considered. The first one was the variety of terms, definitions and classifications of frame markers and lists of lexical items that may count as frame markers. According to Hyland (2005), there is a lack of clarity in the literature concerning what counts as metadiscourse. He therefore concludes that any list of metadiscourse markers can only ever be partial and that metadiscourse can never achieve an exhaustive description. The analysis was based on the list of metadiscourse items that potentially realize frame marker functions divided into the four aforementioned subcategories: sequencing, label stages, announce goals, and shift arguments (cf. ibid.: 218-220). First, the EFL corpus was searched for the frame markers included in the list. Then, all EFL texts were read to identify other frame markers not contained in Hyland's list. The same procedure was repeated for the NS corpus.

Another potential problem was the multifunctionality of metadiscourse items. As Hyland (2005) cautions, metadiscourse items may have different functions in different texts and contexts. They can fulfil two or more functions at the same time: they can express either interactive or interpersonal meanings, and all items can realize either propositional or metadiscursive meanings. Due to the potential multifunctionality, all examples identified in the corpus had to be analysed by referring to the context in which they were used. Namely, the analysis included deciding whether an item referred to the current text or a phenomenon external to the text, as well as making a distinction between interactive or interactional meanings. This is illustrated in Examples 1 to 4: the token now found in the two corpora can realize both propositional and metadiscursive meaning. In Examples 1 and 3 it was used as a time adverbial to order events in time, and is therefore not considered metadiscursive, but in Examples 2 and 4 it labels stages and functions as a metadiscursive item.

\section{EFL corpus}

(1) Now it doesn't seem as a big problem, but in the future it could become catastrophic.

(2) Now let us move on to the drawbacks. 
NS corpus

(3) Now that rail privatisation has gone ahead, many people are likely to lose faith in trains...

(4) Now let us consider the friends or family of the boxer...

Next, there was a possibility that metadiscursive elements performing different functions are used in combinations, which makes it difficult to classify and quantify them. Examples of combinations of different functions per unit were found in both corpora and show that metadiscourse items can realize both interactive and interpersonal meanings. The token now (in Examples 2 and 4), as we have seen, was used to label stages. The tokens let us move on to the drawbacks (in Example 5) and let us consider (in Example 7) realized the interactive meaning and were used to shift topic, whereas tokens let us (in Examples 6 and 8) realized the interactional meaning and were used as an engagement marker.

EFL corpus

Now let us move on to the drawbacks.

(6) Now let us move on to the drawbacks.

NS corpus

(7) Now let us consider the friends or family of the boxer...

(8) Now let us consider the friends or family of the boxer...

These examples can be considered as single metadiscourse units with one general function, or can be interpreted as units containing two or three different types of metadiscursive functions. In the present study we adopted the micro-level perspective (cf. Ädel 2006) in which several occurrences of various types of metadiscourse within a clause were counted as separate tokens. Bearing in mind the previously mentioned difficulties when quantifying metadiscourse, all items that were automatically retrieved were analysed and examined in order to decide whether they qualified as metadiscourse or not. A large number of the retrieved items were found not to have a metadiscursive function and were excluded from further analysis. 
The next step was comparing frequencies of subcategories of frame markers used in learners' essays with their counterparts in the NS corpus. In order to compare the two corpora, the relative frequency representing hits per 10.000 words was calculated for each frame marker in the EFL corpus and for the matching items in the NS corpus. The Kolmogorov-Smirnov test indicated that the EFL corpus data scores do not follow a normal distribution $(\mathrm{D}(74)=0.34, \mathrm{p}<0.010)$. An inspection of individual texts revealed only 17 instances in which the same author used the same items repeatedly, but never more than twice, thus sufficiently meeting the criterion of the independence of observations. Accordingly, the differences in frequencies among subcategories of frame markers between the two corpora were tested applying the non-parametric Kruskal-Wallis test. It has to be noted that we conducted a partial (or one-way) contrastive interlanguage analysis (Granger 1993) so that frequency and statistical comparisons were made only for those items identified in the EFL corpus.

Finally, we explored the relationship between frame marker use, coherence and overall text quality. Coherence was evaluated by a group of trained raters within the KohPiTekst project who followed two sets of criteria. The first set included three elements: 1 ) text type (the degree to which a text complies with conventions of text structure in terms of introduction, body and conclusion; 20 points); (2) cohesion (which encompassed appropriate and efficient use as well as range of cohesive devices; 10 points) and (3) coherence (both local and global; 10 points). The second set included the following criteria: (1) task achievement (5 points), (2) vocabulary (range, appropriateness, orthography; 15 points), and (3) grammar (range and accuracy; 10 points). Each element was evaluated on an assessment scale ranging from 0 to 5 , with a potential maximum of 70 points. The total number of points was taken as an indicator of overall text quality. For the purposes of this study, points for the two coherence subscales (maximum 10) were taken as indicators of text coherence. The Spearman rank correlation was used to explore the relationship between the use of frame markers and coherence.

\subsection{Results}

To answer the first research question, we first looked at the type and token frequency of frame markers used in the two corpora. Table 1 shows the distribution of subcategories of frame marker types in the two corpora. The EFL corpus contained 37 and the NS corpus contained 31 types of frame markers, but the number of types appearing in both corpora is fairly low. A list of frame markers found in the NS corpus can be found in the Appendix. Overall, a higher raw token frequency (i.e. the total number of occurrences of frame markers) was observed in the EFL corpus. On average, L2 writers used 2.64 frame markers 
and L1 writers used 1.26 frame markers per text. In terms of relative frequencies, there were 107.8 frame markers for every 10,000 words in the EFL corpus, compared to 23.5 frame markers per 10,000 words in the NS corpus.

\begin{tabular}{|c|c|c|c|c|c|}
\hline \multirow[b]{3}{*}{$\begin{array}{l}\text { Frame } \\
\text { markers }\end{array}$} & \multicolumn{5}{|c|}{ Frequency (raw) } \\
\hline & \multicolumn{2}{|c|}{ types } & \multirow[b]{2}{*}{$\begin{array}{c}\text { number of } \\
\text { shared types }\end{array}$} & \multicolumn{2}{|c|}{ tokens } \\
\hline & EFL corpus & NS corpus & & EFL corpus & NS corpus \\
\hline sequencing & 19 & 14 & 8 & 139 & 52 \\
\hline label stages & 9 & 13 & 6 & 53 & 17 \\
\hline announce goals & 6 & 3 & 2 & 15 & 3 \\
\hline shift topic & 3 & 0 & 1 & 4 & 1 \\
\hline Total & 37 & 31 & 17 & 211 & 73 \\
\hline
\end{tabular}

Table 1: Type and token frequency of frame markers in EFL and NS corpora

Table 2 shows the raw $(f)$ and relative frequencies $(r f)$ for the subcategory of frame markers used to sequence parts of the text in both corpora. In answer to the second research question, the results show that this was the most frequent subcategory in our corpus. The relative frequency of metadiscourse items marking sequencing is much larger in the EFL corpus than in the NS corpus signalling their overuse by EFL writers.

\begin{tabular}{|l|r|r|r|r|}
\hline \multirow{2}{*}{ Metadiscourse item } & \multicolumn{2}{|c|}{ EFL corpus } & \multicolumn{2}{c|}{ NS corpus } \\
\cline { 2 - 5 } & $\boldsymbol{f}$ & $\boldsymbol{r f}$ & $\boldsymbol{f}$ & $\boldsymbol{r} \boldsymbol{f}$ \\
\hline firstly & 32 & 16.35 & 10 & 3.22 \\
\hline secondly & 32 & 16.35 & 4 & 1.29 \\
\hline another & 22 & 11.24 & 23 & 7.40 \\
\hline (the) first & 10 & 5.11 & 3 & 0.97 \\
\hline first of all & 10 & 5.11 & 1 & 0.32 \\
\hline to begin with & 7 & 3.58 & 0 & 0.00 \\
\hline lastly & 5 & 2.55 & 0 & 0.00 \\
\hline finally & 3 & 1.53 & 3 & 0.97 \\
\hline second of all & 3 & 1.53 & 0 & 0.00 \\
\hline thirdly & 3 & 1.53 & 0 & 0.00 \\
\hline (the) other & 2 & 1.02 & 2 & 0.64 \\
\hline first and foremost & 2 & 1.02 & 0 & 0.00 \\
\hline next & 2 & 1.02 & 1 & 0.32 \\
\hline at last & 1 & 0.51 & 0 & 0.00 \\
\hline last but not least & 1 & 0.51 & 0 & 0.00 \\
\hline
\end{tabular}


Frame Markers and Coherence In L2 Argumentative Essays

\begin{tabular}{|l|c|c|c|c|}
\hline \multirow{2}{*}{ Metadiscourse item } & \multicolumn{2}{|c|}{ EFL corpus } & \multicolumn{2}{c|}{ NS corpus } \\
\cline { 2 - 5 } & $\boldsymbol{f}$ & $\boldsymbol{r f}$ & $\boldsymbol{f}$ & $\boldsymbol{r} \boldsymbol{f}$ \\
\hline subsequently & 1 & 0.51 & 0 & 0.00 \\
\hline the last & 1 & 0.51 & 0 & 0.00 \\
\hline then & 1 & 0.51 & 0 & 0.00 \\
\hline to begin & 1 & 0.51 & 0 & 0.00 \\
\hline
\end{tabular}

Table 2: Frequency of FM: Sequencing

Table 3 shows the results for the frame markers whose function is to label stages and Table 4 shows the results for the frame markers used to announce goals. The relative frequency for both subcategories is yet again much larger in the EFL corpus than in the NS corpus.

\begin{tabular}{|l|c|c|c|c|}
\hline \multirow{2}{*}{ Metadiscourse item } & \multicolumn{2}{|c|}{ EFL corpus } & \multicolumn{2}{c|}{ NS corpus } \\
\cline { 2 - 5 } & $\boldsymbol{f}$ & $\boldsymbol{r f}$ & $\boldsymbol{f}$ & $\boldsymbol{r f}$ \\
\hline (to) conclude & 15 & 7.66 & 4 & 1.29 \\
\hline all in all & 14 & 7.15 & 1 & 0.32 \\
\hline to sum up & 11 & 5.62 & 1 & 0.32 \\
\hline in conclusion & 4 & 2.04 & 2 & 0.64 \\
\hline in the end & 3 & 1.53 & 3 & 0.97 \\
\hline now & 2 & 1.02 & 1 & 0.32 \\
\hline to sum it up & 2 & 1.02 & 0 & 0.00 \\
\hline one can conclude & 1 & 0.51 & 0 & 0.00 \\
\hline to wrap up & 1 & 0.51 & 0 & 0.00 \\
\hline
\end{tabular}

Table 3: Frequency of FM: Label stages

\begin{tabular}{|l|c|c|c|c|}
\hline \multirow{2}{*}{ Metadiscourse item } & \multicolumn{2}{|c|}{ EFL corpus } & \multicolumn{2}{c|}{ NS corpus } \\
\cline { 2 - 5 } & $\boldsymbol{f}$ & $\boldsymbol{r f}$ & $\boldsymbol{f}$ & $\boldsymbol{r}$ \\
\hline in this essay & 7 & 3.58 & 0 & 0.00 \\
\hline would like to & 3 & 1.53 & 2 & 0.64 \\
\hline in this (short) composition & 2 & 1.02 & 0 & 0.00 \\
\hline in order to & 1 & 0.51 & 1 & 0.32 \\
\hline in this writing assignment & 1 & 0.51 & 0 & 0.00 \\
\hline today & 1 & 0.51 & 0 & 0.00 \\
\hline
\end{tabular}

Table 4: Frequency of FM: Announce goals 
Table 5 shows the results for the subcategory of frame markers that function to shift topic. This is the subcategory with the fewest examples found in the corpus. The relative frequency is again larger in the EFL than in the NS corpus.

\begin{tabular}{|l|c|c|c|c|}
\hline \multirow{2}{*}{ Metadiscourse item } & \multicolumn{2}{|c|}{ EFL corpus } & \multicolumn{2}{c|}{ NS corpus } \\
\cline { 2 - 5 } & $\boldsymbol{f}$ & $\boldsymbol{r f}$ & $\boldsymbol{f}$ & $\boldsymbol{r f}$ \\
\hline now & 2 & 1.02 & 1 & 0.32 \\
\hline let us look at the other side of the coin & 1 & 0.51 & 0 & 0.00 \\
\hline let us move on to the drawbacks & 1 & 0.51 & 0 & 0.00 \\
\hline
\end{tabular}

Table 5: Frequency of FM: Shift topic

The next step was to statistically test whether there was a significant difference between the relative frequencies of each subcategory of frame markers in the two corpora (RQ 3). The significance level was set below five per cent $(p<0.05)$. The results are shown in Table 6.

\begin{tabular}{|l|c|c|c|}
\hline \multirow{2}{*}{ Frame markers } & \multicolumn{2}{|c|}{ Relative frequency } & \multirow{2}{*}{ Significance } \\
\cline { 2 - 3 } & $\begin{array}{c}\text { EFL corpus } \\
\text { median }\end{array}$ & $\begin{array}{c}\text { NS corpus } \\
\text { median }\end{array}$ & \\
\hline sequencing $(\mathrm{n}=19)$ & 1.53 & 0.00 & $\mathrm{p}<0.001$ \\
\hline label stages $(\mathrm{n}=9)$ & 1.53 & 0.32 & $\mathrm{p}<0.01$ \\
\hline announce goals $(\mathrm{n}=6)$ & 0.77 & 0.00 & $\mathrm{p}<0.05$ \\
\hline shift topic $(\mathrm{n}=3)$ & 0.51 & 0.00 & $\mathrm{p}<0.05$ \\
\hline $\begin{array}{l}\text { frame markers overall } \\
(\mathrm{n}=37)\end{array}$ & 1.02 & 0.00 & $\mathrm{p}<0.001$ \\
\hline
\end{tabular}

Table 6: Differences in frame marker use between EFL and NS corpus

The Kruskal-Wallis test showed significant differences between relative frequencies of each subcategory of frame markers, as well as overall frame markers in EFL and NS texts. Graph 1 illustrates the results more clearly and evidently points to the tendency of L2 writers to overuse frame markers. 


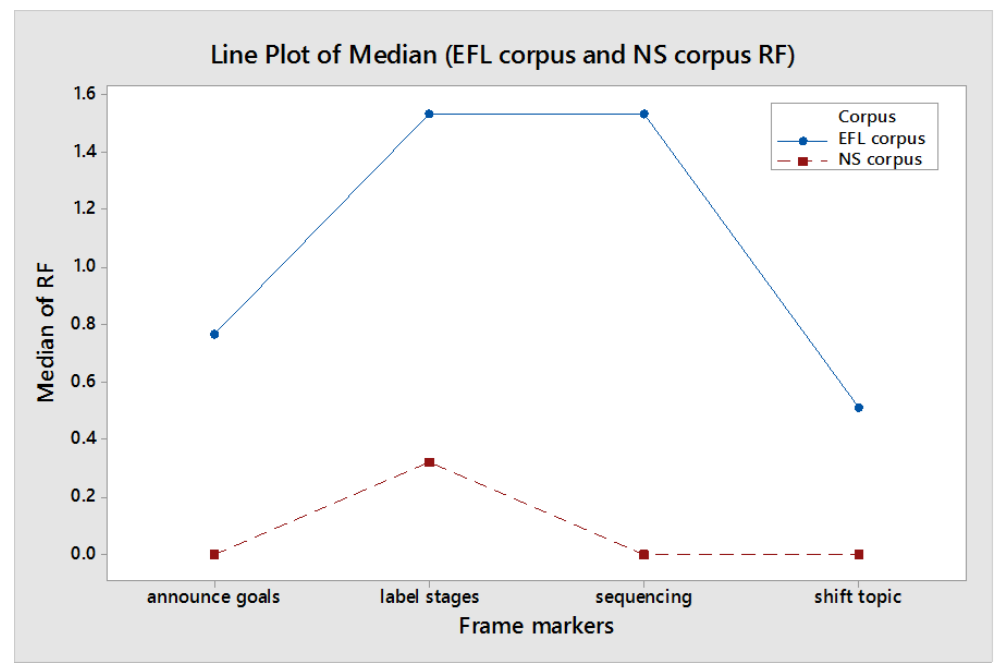

Graph 1: Relative frequencies of each subcategory of frame markers

\begin{tabular}{|l|c|c|c|c|c|}
\hline & \multicolumn{4}{|c|}{ Frame markers: } & \\
\hline & sequencing & label stages & $\begin{array}{c}\text { announce } \\
\text { goals }\end{array}$ & shift topic & total FM \\
\hline coherence & 0.02 & 0.09 & -0.22 & 0.05 & -0.02 \\
\hline text quality & 0.09 & 0.14 & -0.15 & 0.01 & 0.08 \\
\hline
\end{tabular}

Table 7: Spearman correlations between frame markers in EFL texts and coherence and overall EFL text quality

A series of Spearman rank correlations were conducted in order to determine if there were any relationships between coherence and overall text quality and the use of the four subcategories of frame markers as well as overall use of frame markers (RQ 4). Text coherence was rated according to the analytical rating scale described in Section 5.2. The results in Table 7 indicate that no statistically significant correlations were found between the variables. A comparison of texts based on their quality showed that there were on average 2.8 frame markers in high-rated essays (scoring above 55 points) and 2.4 in low-rated essays. The Kruskal Wallis test showed that this difference was not statistically significant $(\mathrm{H}=1.05, \mathrm{p}=0.306)$. 


\section{Discussion and conclusion}

In the present study we analysed typical features and patterns of early undergraduate L2 English learners' use of frame markers in comparison to native speakers' choices and explored the relationship between frame marker use and coherence and overall text quality in L2 texts.

According to our expectations, the results showed that L2 learners tend to select and overuse a particular set of frame markers, especially those for sequencing and labelling stages. It transpired that one of the characteristics of L2 writers' use of frame markers is that they seem to have adopted individual items, such as firstly or (to) conclude, which they keep using to express certain functions (cf. Pavičić Takač 2018). This is unsurprising, because both subcategories are an important characteristic of argumentative essays for they sequence parts of the text, order an argument and explicitly label text stages. Frequency analysis also pointed to statistically significant differences in relative frequencies of all frame markers between the EFL and the NS corpora. The results therefore reveal features of L2 writers' use of metadiscourse observed in previously mentioned studies (cf. Section 4). However, L2 writers' overuse of frame markers does not consequentially imply that NS underuse them. NS may select other, less overt, means of framing their argument, such as anaphoric/cataphoric reference or use of tenses. This may point to L2 learners' deficient knowledge of ways of achieving coherence leading to their overreliance on explicit markers, or, at least, resorting to avoidance strategy.

Being familiar with the teaching practice in Croatia, we are inclined to conclude that the results may be a consequence of the aforementioned fact that the L2 learners' first (and often only) encounter with the non-disciplinespecific genre of argumentative essay is in foreign language classes. Secondly, learners are exposed only to the explicit teaching of simplistic lists of English metadiscourse items whose meanings and functions are not sufficiently elaborated and exemplified, while other types of cohesive devices are largely neglected. As Milton (2001) stresses, such approach to teaching is not uncommon because teachers perceive teaching lists of words and phrases as unproblematic and are guided by the idea that cohesion (i.e. metadiscourse) is the main way to coherence. Consequently, learners often learn few examples from a particular category of metadiscourse which they use almost randomly, without understanding subtle differences in meaning between similar items. What is more, their texts seem to be composed around those items in that they accommodate propositions to metadiscourse rather than conversely.

Next, as writing an argumentative essay is one of the tasks at the national school-leaving exam, the potential washback effect must also be taken into 
account. As Ädel (2006: 19) states, "the implied reader exerts considerable influence on the writer and, consequently, on the text". Translated to the task of writing argumentative essays, the implied reader is the evaluator. L2 writers are well-aware of both the pending evaluation and the criteria used to judge their writing which explicitly include the use of cohesive devices. Also, they are well trained to meet them. This often results in the overuse or ineffective use of a limited number of metadiscourse items, which does not add to coherence, or the informativity of the texts. Of course, this evaluation criterion can have positive consequences if it induces learners to expand their range of metadiscourse items. The overuse of frame markers may therefore also be understood as the learners' test taking strategy: they may be looking for ways of complying with task requirements and targeting the required number of words (cf. Ädel 2006: 109).

Contrary to our anticipation, the correlational analysis revealed no statistically significant relationship between the use of frame markers and coherence. This would imply that L2 learners' use of frame markers is ineffective and does not contribute to creating more coherent texts. A possible explanation, yet again, is that L2 learners may have used these frame markers solely in order to comply with task requirements without considering their role in achieving text coherence. A closer inspection of this subcategory of frame markers identified in the EFL corpus, such as in this essay or in this writing assignment, shows that they were used in the introduction, which would be acceptable had they been used to introduce relevant propositional content. In most of these cases, however, learners failed to properly present their ideas, and - in the absence of the propositional content - metadiscourse items were used simply to inflate the number of words.

The lack of statistically significant correlation between frame markers and coherence may be explained by the fact that the analysis was limited to one category of metadiscourse and a relatively small sample size. It may also be reflective of how coherence was operationalized, i.e. the rating method applied. A focus on one metadiscourse category on the one hand and a holistic appraisal of coherence on the other may not have provided enough data to gain more insight into the role of metadiscourse in text coherence. The conclusions drawn must be taken with some caution because of the limitations of the study which include, but are not limited to, the small corpus size and the focus on one interactive metadiscourse category.

\section{Practical implications and new avenues of research}

Using metadiscourse appropriately and effectively is not an easy task for L2 novice writers. Crismore et al. (1993) attribute this to the assumption that, 
despite potential universalilites across languages, some metadiscourse categories are differently used in different languages: some may be frequently used in one language but not in another, or the linguistic devices used for some types of metadiscourse may be very different in two languages. Another difficultyinducing factor is the multifunctionality of metadiscourse items, which may also cause problems for learners who, in their attempt to translate such items, fail to appropriately convey their meaning and function. Therefore, more detailed and systematic cross-linguistic metadiscourse studies may be beneficial for the development of both L1 and L2 writing skills (Crismore et al. 1993).

The principal conclusion based on our findings would be that explicit teaching of basic lists of metadiscourse items without raising awareness of their distinctive features and functions does not suffice. This seems to be in line with suggestions put forward in previous studies on metadiscourse. Cheng and Steffensen (1996) and Steffensen and Cheng (1996), for example, showed that direct teaching of metadiscourse and its pragmatic/rhetorical functions leads to enhanced awareness of the role of metadiscourse, more effective use of metadiscourse markers, and increased quality of the texts produced. Learners in their studies were able to move away from regarding "the metadiscourse markers as empty fillers with low informativity to recognizing their pragmatic functions" (Steffensen \& Cheng 1996: 167) and thereby reduce the excessive and ineffective use of metadiscourse and start using a variety of metadiscourse items.

The results of the present study also suggest that EFL writers' ineffective use of frame markers could be an outcome of the negative washback effect. This implies that, we dare say, first the teachers and then consequently their learners fail to understand that metadiscourse is not an artificial textual intervention used to simply embellish the text. Clearly, this implies pursuing avenues of possible interventions in teacher training as well as the further study of the washback effect on teachers, evaluators and learners.

The discussion so far boils down to one general practical implication: it is the particular pragmatic functions of metadiscourse that should be in the forefront of instruction. They should be illustrated by examples of typical academic moves that clearly show how and where in the text one might introduce metadiscourse to assist coherence and effectiveness of the text. As Ädel (2006) emphasises, in certain contexts some kind of metadiscourse can be more appropriate than others, and in some contexts it might even be required. These features can be extracted, classified and taught to students to enable them to write more effectively. To conclude, explicit teaching of metadiscourse must include the explication of the concept of metadiscourse, its categories, functions, and multifunctionality. More effective results could be achieved by means of data-driven learning 
based on authentic materials which demonstrate how metadiscourse functions in context. A comparison with native-speaker corpora is necessary because they represent examples of real-life language use. If learners are to acquire writing skills applicable in their future professional or academic writings, they must be provided with good models (cf. Shaw 2009). We also believe that learner corpora, such as ours, and their comparison with native-speaker corpora can serve as a starting point for analysis, because they contain examples of both effective and ineffective use of metadiscourse in written texts. Such comparisons may reveal not only the typical errors learners make but also the patterns of transfer from L1 to L2, as well as clarify what causes problems in the EFL learners' metadiscourse use. In fact, these are some of the many issues that might be addressed more systematically in future research. A more comprehensive study may entail a detailed comparison of all types of metadiscourse items in order to provide a better understanding of the underlying issues. We hope that the ensuing analyses within the KohPiTekst project, or any pertinent future studies, will address some of the issues raised and tackle the limitations of the present study.

As has been demonstrated in the present study, computer-assisted tools can be used in the exploration of the role of metadiscourse in establishing coherence, but one must bear in mind that metadiscourse is a highly context-dependent phenomenon and computer-assisted methods must be accompanied by manual analysis. As Ädel (2006) speculates, there may be ways to get around the context-dependence for at least some categories of metadiscourse. Hopefully, future research will generate specially-designed corpus tools with more complex search algorithms that would enable researchers to conduct more intricate automatic analysis of metadiscourse.

\section{Notes}

1 This work has been supported by the Croatian Science Foundation under the project 1P-2016-065736: Textual Coherence in Foreign Language Writing (KohPiTekst).

2 SketchEngine generates two pieces of information: words and tokens. Each word and punctuation is a separate token, so corpora contain more tokens than words. In this paper the term token is used but it does not include punctuation, i.e. refers to what is termed word in Sketch Engine.

\section{References}

Ädel, A. (2006) Metadiscourse in L1 and L2 English. Philadelphia: John Benjamins.

Alipour, M., Jahangard, A. and Bemani, M. (2015) 'Metadiscourse across three varieties of argumentative essays by university students: Native English, Iranian EFL learners and native Persian.' English for Specific Purposes World 16(45), 1-16.

Altenberg, B. and Tapper, M. (1998) 'The use of adverbial connectors in advanced Swedish learners' written English.’ In: Granger, S. (ed.) Learner English on Computer. Harlow: Longman. 80-93. 
Aull, L. L. and Lancaster, Z. (2014) 'Linguistic markers of stance in early and advanced academic writing: A corpus-based comparison.' Written Communication 31(2), 151-183.

Bachman L. F. (1990) Fundamental Considerations in Language Testing. Oxford: Oxford University Press.

Bachman, L. and Palmer, A. (1996) Language Testing in Practice: Designing and Developing Useful Language Tests. Oxford: Oxford University Press.

Bagarić Medve, V. and Pavičić Takač, V. (2013a) Jezična i strategijska kompetencija u stranome jeziku. [Linguistic and Strategic Competence in a Foreign Language]. Osijek: University of Osijek. Filozofski fakultet.

Bagarić Medve, V. and Pavičić Takač, V. (2013b) 'The influence of cohesion and coherence on text quality: A cross-linguistic study of foreign language learners' written production.' In: Piechurska-Kuciel, E. and Szymanska-Czaplak, E. (eds) Language in Cognition and Affect. Berlin-Heidelberg: Springer. 111-131.

Biber, D., Johansson, S., Leech, G., Conrad, S. and Finegan, E. (1999) Longman Grammar of Spoken and Written English. New York: Pearson.

Bolton, K., Nelson, G. and Hung, J. (2002) 'A corpus-based study of connectors in student writing: Research from The International Corpus of English in Hong Kong (ICE-HK).' International Journal of Corpus Linguistics 7(2), 165-182.

Brown, G. and Yule, G. (1983) Discourse Analysis. Cambridge: Cambridge University Press.

Canale, M. (1983) 'From communicative competence to communicative language pedagogy.' In: Richards, J. C. and Schmidt, R. W. (eds) Language and Communication. London: Longman. 2-27.

Carrell, P. (1982). 'Cohesion is not coherence.' TESOL Quarterly 16, 479-488.

Celce-Murcia, M. (1995) 'The elaboration of sociolinguistic competence: Implications for teacher education.' In: Alatis, J. E., Straehle, C. A. and Ronkin, M. (eds) Linguistics and the Education of Language Teachers: Ethnolinguistic, Psycholinguistic, and Sociolinguistic Aspects. Proceedings of the Georgetown University, Round Table on Languages and Linguistics. Georgetown University Press, Washington DC. 699-710.

Celce-Murcia, M. (2007) 'Rethinking the role of communicative competence in language teaching.' In: Alcón Soler, E. and Safont Jordà, M. P. (eds) Intercultural Language Use and Language Learning. Dordrecht: Springer. 41-57.

Chen, C. W. (2006) 'The use of conjunctive adverbials in the academic papers of advanced Taiwanese EFL learners.' International Journal of Corpus Linguistics 11(1), 113-130.

Chen, C. and Zhang, L. J. (2017) 'An intercultural analysis of the use of hedging by Chinese and Anglophone academic English writers.' Applied Linguistics Review 8(1), $1-34$.

Cheng, X. and Steffensen, M. S. (1996) 'Metadiscourse: A technique for improving student writing.' Research in the Teaching of English 30(2), 149-181.

Council of Europe (2001) Common European Framework of Reference: Learning, Teaching, Assessment (CEFR). Cambridge: Cambridge University Press.

Crismore, A. (1989) Talking with Readers: Metadiscourse as Rhetorical Act. New York: Peter Lang.

Crismore, A. and Farnsworth, R. (1990) 'Metadiscourse in popular and professional science discourse.' In: Nash, W. (ed.) The Writing Scholar: Studies in Academic Discourse. Newbury Park, CA: Sage. 119-136.

Crismore, A., Markkanen, R. and Steffensen, M. (1993) 'Metadiscourse in persuasive writing: A study of texts written by American and Finnish university students.' Written Communication 10, 39-71. 
Dahl, T. (2004) 'Textual metadiscourse in research articles: A marker of national culture or of academic discipline?' Journal of Pragmatics 36, 1807-1825.

Dastjerdi, H. V. and Talebinezhad, R. M. (2006) 'Chain-preserving deletion procedure in cloze: A discoursal perspective.' Language Testing 23(1), 58-72.

Granger, S. (1993) 'The International Corpus of Learner English.' In: Aarts, J., de Haan, P. and Oostdijsk, N. (eds) English Language Corpora: Design, Analysis and Exploitation. Amsterdam and Atlanta: Rodopi. 57-71.

Granger, S. and Tyson, S. (1996) 'Connector usage in the English essay writing of native and non-native EFL speakers of English.' World Englishes 15(1), 17-27.

Grant, L. and Ginther, A. (2000) 'Using computer-tagged linguistic features to describe L2 writing differences.' Journal of Second Language Writing 9, 123-145.

$\mathrm{Hu}, \mathrm{G}$. and Cao, F. (2011) 'Hedging and boosting in abstracts of applied linguistics articles: A comparative study of English- and Chinese-medium journals.' Journal of Pragmatics 43(11), 2795-2809.

Hůlková, I. (2005) 'Linking devices in English academic prose.' In: Povolná, R. and Dontcheva-Navratilova, O. (eds) Discourse and Interaction 1. Brno Seminar on Linguistic Studies in English. Proceedings. Brno: Masarykova univerzita. 53-60.

Halliday, M. A. K. and Hasan, R. (1976) Cohesion in English. London: Longman.

Halliday, M. A. K. (1994) An Introduction to Functional Grammar. $2^{\text {nd }}$ ed. London: Edward Arnold.

Hyland, K. (1998) 'Persuasion and context: The pragmatics of academic metadiscourse.' Journal of Pragmatics 30, 437-455.

Hyland, K. (2004) 'Disciplinary interactions: Metadiscourse in L2 postgraduate writing.' Journal of Second Language Writing 13(2), 133-151.

Hyland, K. (2005) Metadiscourse: Exploring Interaction in Writing. London: Continuum. Intaraprawat, P. and Steffensen, M. S. (1995) 'The use of metadiscourse in good and poor ESL essays.' Journal of Second Language Writing 4(3), 253-272.

Jafarpur, A. (1991) 'Cohesiveness as a basis for evaluating compositions.' System 19(4), 459-465.

Johansson, S. (1998) 'On the role of corpora in cross-linguistic research.' In: Johansson, S. and Oksefjell, S. (eds) Corpora and Cross-linguistic Research: Theory, Method, and Case Studies. Amsterdam: Rodopi. 3-25.

Jucker, A. H. and Ziv, Y. (1998) 'Discourse markers: Introduction.' In: Jucker, A. and Ziv, Y. (eds) Discourse Markers. Descriptions and Theory. Amsterdam and Philadelphia: John Benjamins. 1-13.

Kennedy, C. and Thorp, D. (2002) A Corpus-based Investigation of Linguistic Responses to an IELTS Academic Writing Task. Birmingham: University of Birmingham.

Knoch, U., Macqueen, S. and O'Hagan, S. (2014) An Investigation of the Effect of Task Type on the Discourse Produced by Students at Various Score Levels in the TOEFL $i B T ®$ Writing Test. (TOEFL iBT Report No. 23, ETS Research Report No. RR-14-43). Princeton, NJ: Educational Testing Service.

Kobayashi, Y. (2016) 'Investigating metadiscourse markers in Asian Englishes: A corpusbased approach.' LIF - Language in Focus Journal 2(1), 19-35.

Mauranen, A. (1993) 'Contrastive ESP rhetoric: Metatext in Finnish-English economics texts.' English for Specific Purposes 12(1), 3-22.

Milton, J. (2001) 'Elements of a written interlanguage: A computational and corpusbased study of institutional influences on the acquisition of English by Hong Kong Chinese students.' PhD. thesis. Hong Kong: The Hong Kong University of Science and Technology. 
Milton, J. C. and Tsang, E. S. C. (1993) 'A corpus-based study of logical connectors in EFL students' writing: Directions for future research.' In: Pemberton, R. and Tsang, E. S. C. (eds) Studies in Lexis. Hong Kong: The Hong Kong University of Science and Technology Language Center. 215-246.

Mirshamsi, A. and Allami, H. (2013) 'Metadiscourse markers in the discussion/conclusion section of Persian and English master's theses.' The Journal of Teaching Language Skills 32(3), 23-40.

Mu, C., Zhang, L. J., Ehrich, J. and Hong, H. (2015) 'The use of metadiscourse for knowledge construction in Chinese and English research articles.' Journal of English for Academic Purposes 20, 135-148.

Mur-Dueñas, P. (2011) 'An intercultural analysis of metadiscourse features in research articles written in English and in Spanish.' Journal of Pragmatics 43(12), 3068-3079.

Murillo, S. (2012) 'The use of reformulation markers in Business Management research articles. An intercultural analysis.' International Journal of Corpus Linguistics 17(1), 64-90.

Narita, M., Sato C. and Suguira, M. (2004) 'Connector usage in the English essay writing of Japanese EFL learners'. Proceedings of the 4th International Conference on Language Resources and Evaluation 1(1), 1171-1174.

Pavičić Takač, V. (2018) 'Sentence-initial interactive metadiscourse and text coherence in EFL argumentative essays.' Lonaka Journal of Learning and Teaching 9(2), 13-29.

Povolná, R. (2016) 'A cross-cultural analysis of conjuncts as indicators of the interaction and negotiation of meaning in research articles.' Topics in Linguistics 17(1), 45-63.

Savignon, S. J. (1983) Communicative Competence: Theory and Classroom Practice. Texts and Contexts in Second Language Learning. Reading, Massachusetts: AddisonWesley Publishing Company.

Shaw, P. (2009) 'Linking adverbials in student and professional writing in literary studies: What makes writing mature.' In: Charles, M., Pecorari, D. and Hunston, S. (eds) Academic Writing: At the Interface of Corpus and Discourse. London and New York: Continuum. 215-235.

Steffensen, M. S. and Cheng, X. (1996) 'Metadiscourse and text pragmatics: How students write after learning about metadiscourse.' In: Bouton, L. F. (ed.) Pragmatics and Language Learning. Monograph Series 7. 153-70.

Vande Kopple, W. J. (1985) 'Some explanatory discourse on metadiscourse.' College Composition and Communication 36, 82-93.

van Dijk, T. A. (1977) Text and Context. Explorations in the Semantics and Pragmatics of Discourse. New York: Longman.

Vogel, R. (2008) 'Sentence linkers in essays and papers by native vs. non-native writers.' Discourse and Interaction 1(2), 119-126.

Widdowson, H. G. (1978) Teaching Language as Communication. Oxford: Oxford University Press.

Wolfe-Quintero, K., Inagaki, S. and Kim, H. Y. (1998) Second Language Development in Writing: Measures of Fluency, Accuracy, and Complexity. Honolulu: University of Hawaii. 
Frame Markers and Coherence In L2 Argumentative Essays

APPENDIX: List of frame markers in NS corpus (not found in EFL corpus)

\begin{tabular}{|l|c|}
\hline Frame marker & frequency \\
\hline sequencing & 1 \\
\hline the next & 2 \\
\hline numbering $(1,2,3)$ & \\
\hline label stages & 1 \\
\hline as a conclusion & 1 \\
\hline in concluding & 2 \\
\hline in short & 1 \\
\hline summing up & \\
\hline announce goals & 1 \\
\hline the essay will have four sections & 1 \\
\hline wish to & $\mathbf{1 0}$ \\
\hline TOTAL & \\
\hline
\end{tabular}

Višnja Pavičić Takač is Professor of English Applied Linguistics in the Department of English Language and Literature at the University of Osijek, Croatia. Her research interests include individual differences in foreign language learning, language learning strategies, communicative competence, lexical development and discourse competence. She is an executive editor of Strani jezici, and a member of the editorial boards of two other linguistic journals. She is currently involved in the project Textual Coherence in Foreign Language Writing, which deals with the description and comparison of coherence features and the ways of developing coherence in texts written by foreign language learners of German, English, Hungarian, French, and Croatian compared to coherence properties and the ways of developing textual coherence in their respective first languages.

Address: Višnja Pavičić Takač, Department of English Language and Literature, Faculty of Humanities and Social Sciences, Josip Juraj Strossmayer University, Jägerova 9,31000 Osijek, Croatia. [e-mail: vpavicic@ffos.hr]

Sanja Ivezić Vakanjac is a Ph.D. student of linguistics at the University of Osijek, Croatia, and a secondary school teacher of English and German. She is a trained evaluator for the National School-leaving Exam in English. Her doctoral research focuses on features of metadiscourse in learners of English as a foreign language.

Address: Sanja Vakanjac Ivezić, Faculty of Humanities and Social Sciences, Josip Juraj Strossmayer University, Jägerova 9, 31000 Osijek, Croatia. [e-mail: sanja.svi@gmail.com] 